\title{
Inhibitory effect of thyme and cinnamon essential oils against $E$. coli O157:H7 in Tahini
}

\author{
Anas AL-NABULSI ${ }^{1 *}$ (D), Tareq OSAILI ${ }^{1,2}$, Amin OLAIMAT $^{3}$, Weam ALMASRI ${ }^{1}$, Murad Al-HOLY ${ }^{3}$, \\ Ziad JARADAT ${ }^{4}$, Mutamed AYYASH ${ }^{5}$, Saddam AWAISHEH ${ }^{6}$, Richard HOLLEY ${ }^{7}$
}

\begin{abstract}
Tahini is a common food product in the Mediterranean area that is used as a main ingredient in variety of ready-to-eat foods. The objective of the current study was to investigate the inhibitory effect of thyme oil (TO) or cinnamon oil (CO) on E. coli O157:H7 viability in tahini and diluted tahini at different storage temperatures. Addition of $2.0 \% \mathrm{CO}$ to tahini reduced E. coli O157:H7 numbers by $1.38,1.79$ or $2.20 \log _{10} \mathrm{CFU} / \mathrm{mL}$ at 10,25 or $37{ }^{\circ} \mathrm{C}$, respectively, by $28 \mathrm{~d}$. In diluted tahini at $10^{\circ} \mathrm{C}$, no viable cells of $E$. coli $\mathrm{O} 157: \mathrm{H} 7$ by $21 \mathrm{~d}$ were detected when $1.0 \% \mathrm{CO}$ was used. However, at 25 and $37^{\circ} \mathrm{C}$, no viable cells were detected by $14 \mathrm{~d}$ when $\mathrm{CO}$ was added at $0.5 \%$ level. Addition of $2.0 \%$ TO to tahini, resulted in $1.82,2.01$ or $1.65 \log _{10} \mathrm{CFU} / \mathrm{mL}$ reduction in E. coli O 157: $\mathrm{H7}$ numbers was noted at 37,25 or $10^{\circ} \mathrm{C}$, respectively, by $28 \mathrm{~d}$. In diluted tahini, TO at $0.5 \%$ or $1.0 \%$ induced complete reduction in the viability of E. coli O157:H7 by $28 \mathrm{~d}$ storage at 37 or $25^{\circ} \mathrm{C}$. At $10{ }^{\circ} \mathrm{C}$, a $3.02 \log _{10} \mathrm{CFU} / \mathrm{mL}$ reduction was observed by $28 \mathrm{~d}$ compared to the initial inoculation level in samples treated with $2.0 \% \mathrm{TO}$.
\end{abstract}

Keywords: tahini; E. coli O157: H7; cinnamon oil; thyme oil.

Practical Application: Control the growth of E. coli O157:H7 in tahini using thyme oil or cinnamon oil.

\section{Introduction}

Tahini or sesame paste is a common component of several popular ready-to-eat (RTE) dishes including tahini salad, halva (sweetened tahini), hummus, tarator sauce and mutabbel in Middle Eastern countries including Jordan, and it is also involved in several other ethnic dishes in Greek, North African and Turkish cuisines. The worldwide tahini consumption or its products has raised during the past few years, particularly in the European countries, US and Canada due to its nutritional value and health properties. For example, tahini has moderate amount of carbohydrate (6.4-9.0\% wt) and high amount of protein $(23-27 \% \mathrm{wt})$ as well as lipid (57-65\% wt) and vitamins and minerals (Sawaya et al., 1985; Abu-Jdayil et al., 2002). Further, it has been reported that sesame seed products like tahini play a crucial role in preventing cardiovascular diseases and atherosclerosis, improving digestion and metabolic activity and reducing hyperglycemia and cholesterol (Narasimhulu et al., 2015). It is also anticipated that the global consumption of tahini will increase by $12 \%$ in the next 5 years. It is expected that the Middle East and the US will be the main consumption regions due to the increasing demand for ethnic Arabic and Mediterranean foods, and seed-based spreads. The US alone was responsible for $78 \%$ of the total global tahini consumption in 2015 (Research \& Markets, 2017).

Tahini is a RTE product that has a low water activity, $\mathrm{a}_{\mathrm{w}}$ $(\sim 0.16-0.25)$ and an extended shelf-life (two years) when stored at ambient temperature. However, its high fat content provides opportunity for microorganisms to survive for long time under different storage environments (Lake et al., 2010). Tahini nowadays has raised a special concern regarding its safety, particularly to both the food regulatory agencies and food industry in view of recent reports of recalls and outbreaks associated with tahini contaminated with pathogenic bacteria. Numerous foodborne recalls and outbreaks linked to consumption of tahini or its products have been documented worldwide in the last two decades, particularly due to their contamination with Salmonella serovars (Unicomb et al., 2005; Centers for Disease Control and Prevention, 2012, 2013). Furthermore, E. coli O157:H7 has been isolated from tahini or tahini-based products. E. coli O157:H7 is also able to survive and grow in commercial and diluted tahini during storage at temperature range of 10 to $37^{\circ} \mathrm{C}$ (Al-Nabulsi et al., 2013). Consequently, control of foodborne pathogens in tahini is likely to require novel approaches, including those based on using natural antimicrobials instead of chemical preservatives, which is of popular consumer interest for consumers worldwide, and hence this approach has been utilized in the current study.

Plant-derived antimicrobial substances like essential oils (EOs) have been used for hundreds of years as a mean of inhibiting spoilage and pathogenic microorganisms (Al-Nabulsi et al., 2015). Some edible oils, medicinal herbs and spices are potently effective against different foodborne pathogens such as E. coli O157:H7 in

Received 04 Sept., 2019

Accepted 18 Nov., 2019

${ }^{1}$ Department of Nutrition and Food Technology, Faculty of Agriculture, Jordan University of Science and Technology, Irbid, Jordan

${ }^{2}$ Department of Clinical Nutrition and Dietetics, University of Sharjah, Sharjah, United Arab Emirates

${ }^{3}$ Department of Clinical Nutrition and Dietetics, Faculty of Applied Medical Sciences, The Hashemite University, Zarqa, Jordan

${ }^{4}$ Department of Biological and Genetic Engineering, Jordan University of Science and Technology, Irbid, Jordan

${ }^{5}$ Department of Food, Nutrition and Health, United Arab Emirates University, Al-Ain, United Arab Emirates

${ }^{6}$ Department of Nutrition and Food Technology, Al-Balqa Applied University, Salt, Jordan

${ }^{7}$ Department of Food and Human Nutritional Sciences, University of Manitoba, Winnipeg, MB, Canada

*Corresponding author: anas_nabulsi@just.edu.jo 
a variety types of food system (Tajkarimi et al., 2010). However, the inhibitory effects of plant EOs against E. coli O157:H7 in tahini have not been investigated. Therefore, the objectives of this study were to: i) screen the antibacterial activity of 14 plant EOs against three E. coli O157:H7 strains using disc-diffusion method at 10 and $37^{\circ} \mathrm{C}$; ii) determine the minimum inhibitory (MICs) and minimum bactericidal concentrations (MBCs) of cinnamon and thyme oils (the most potent essential oils) against E. coli O157:H7; and iii) investigate the inhibitory activity of cinnamon and thyme oils against $E$. coli O157:H7 cocktail in commercial or diluted tahini which was used as a model for tahini-based products) stored at 10,25 or $37^{\circ} \mathrm{C}$.

\section{Materials and methods}

\subsection{Preparation of bacterial cultures}

Three mutated non-pathogenic (verotoxigenic negative) E. coli O157:H7 strains (02:0627, 02:0628, 00:3581), that had been provided by Rafiq Ahmed, National Microbiology Laboratory, Public Health Agency, Canadian Science Centre for Human and Animal Health, Winnipeg, MB. Canada, were used in the present study. The strains were individually kept and maintained in Brain Heart Infusion (BHI, Oxoid Ltd, Basingstoke, UK) broth including $20 \%(\mathrm{v} / \mathrm{v})$ glycerol at $-40{ }^{\circ} \mathrm{C}$. A loopful of each thawed frozen strain was streakedonto the plates surface of Sorbitol MacConkey agar (SMA, Oxoid Ltd, Basingstoke, UK), followed by incubation at $37^{\circ} \mathrm{C}$ for $24 \mathrm{~h}$. Thereafter, a colony of each individual strain was transferred to $\mathrm{BHI}$ broth which was incubated for $24 \mathrm{~h}$ at $37^{\circ} \mathrm{C}$. Three consecutive transfers were performed to revitalize the bacterial culture and a final transfer to BHI broth was conducted before the experiment. The inoculated BHI broth was incubated for $24 \mathrm{~h}$ at $37^{\circ} \mathrm{C}$ to allow E. coli to reach the stationary phase.

\subsection{Preparation of cocktail culture}

After culturing E. coli O157:H7 in BHI broth, the cells were harvested by centrifugation at $4000 \times g$ for $15 \mathrm{~min}$. The pellet was obtained after discarding the supernatant. Thereafter, $10 \mathrm{~mL}$ of $0.1 \%$ sterile peptone water (Oxoid Ltd, Basingstoke, UK) was mixed with the pellets. The E. coli O157:H7 count in the resulting bacterial suspension was determined by plating onto SMA and a final bacterial concentration of $\sim 9 \log _{10} \mathrm{CFU} / \mathrm{mL}$ was obtained. The suspension was diluted with $0.1 \%$ peptone water to the desired concentration and $2.5 \mathrm{~mL}$ of each E. coli O157:H7 strain was combined to form a cocktail mixture of the three strains.

\subsection{Essential oil extracts}

The inhibitory effect of 14 EOs of medicinal plants were screened in this study; lavender, thyme, cardamom, rosemary, mint, cinnamon, fir, sage, laurel leaves, ginger, mustard, radish seeds, black cumin seeds and pomegranate seeds. These EOs were purchased from Green Field Oil Factory in Amman, Jordan. Hydro-distillation is usually used in this factory to extract the EOs from their sources with a purity of $99 \%$. The EOs were kept dry in sealed dark glass vials at $4{ }^{\circ} \mathrm{C}$ until use.

\subsection{Screening of inhibitory effect of plant EOs}

The inhibitory effect of the 14 plant EOs against E. coli O157:H7 strains was screened using the disc diffusion method (Janakat et al., 2015). Specifically, $20 \mu \mathrm{L}$ of each plant EO were spread onto sterile discs with diameter of $6 \mathrm{~mm}$ (Oxoid Ltd, Basingstoke, UK) which were air dried at room temperature for 10 min under a bio-safety cabinet. The discs were placed onto TSA plates that had been inoculated with $100 \mu \mathrm{L}$ solution containing $\sim 6.0 \log _{10} \mathrm{CFU} / \mathrm{mL}$ of each individual E. coli O157:H7 strain. Thereafter, the plates were incubated for $24 \mathrm{~h}$ at $37^{\circ} \mathrm{C}$ or for $7 \mathrm{~d}$ at $10^{\circ} \mathrm{C}$. A calibrated ruler was used for measuring the inhibition zones in $\mathrm{mm}$

\subsection{Determination of the MICs and MBCs of most potent EOs against E. coli O157:H7 (02:0627)}

Of the 14 EOs, the MIC and the MBC of only thyme oil and cinnamon oil were determined using the microdilution method, since these oils showed the strongest inhibitory effect against E. coli $\mathrm{O} 157: \mathrm{H} 7$ strains. Briefly, $100 \mu \mathrm{L}$ of fresh cultures were diluted in Mueller Hinton (MH) broth (Oxoid Ltd, Basingstoke, UK) to give a final concentration of about $5.0 \log _{10}$ $\mathrm{CFU} / \mathrm{mL}$ of E. coli O157:H7 (02:0627). Cinnamon or thyme oils were individually mixed at a ratio of $1: 1$ in $0.5 \%$ dimethyl sulfoxide (DMSO, HPLC grade). Volumes of 50, 100 or $150 \mu \mathrm{L}$ of DMSO-essential oil solution were added to 96 well microtiter plates (Greiner Bio-One, CellStar ${ }^{\mathrm{Tw}}$, Italy). Thereafter, the volume to $250 \mu \mathrm{L}$ was completed with sterile distilled water. A solution of $0.5 \%$ DMSO without cinnamon or thyme oil was mixed with the bacterial culture as a positive control, while DMSO containing cinnamon or thyme oil was used as a negative control. Then, the sealed microplate was incubated for $24 \mathrm{~h}$ at $37^{\circ} \mathrm{C}$. Then, $100 \mu \mathrm{L}$ aliquots from each sample were taken and decimal dilutions were prepared with $0.1 \%$ peptone water. Exactly $100 \mu \mathrm{L}$ from each of the appropriate dilutions was spread onto the surface of TSA (Oxoid) and incubated for $24 \mathrm{~h}$ at $37^{\circ} \mathrm{C}$.

\subsection{Tahini preparation}

Tahini samples were purchased from a local market in Irbid, Jordan. Samples were tested for the presence of E. coli O157:H7 prior to its use and confirmed to be free from contamination. Diluted tahini $(10 \% \mathrm{w} / \mathrm{v})$ was prepared by mixing $2.5 \mathrm{~g}$ tahini with $22.5 \mathrm{~mL}$ sterile distilled water in sterile Duran bottle. A cocktail mixture of $E$. coli $\mathrm{O} 157: \mathrm{H} 7$ was inoculated into tahini and diluted tahini to obtain $\sim 4.5 \log _{10} \mathrm{CFU} / \mathrm{mL}$. Thereafter, $0.0,0.2,0.5,1.0$ or $2.0 \%$ $(\mathrm{v} / \mathrm{v})$ of cinnamon or thyme EOs, which were prepared as formerly described were added to tahini or diluted tahini. Each bottle was agitated using a vortex mixer (Velp, Italy) to distribute the bacterial culture uniformly throughout the samples, and were incubated at 37,25 or $10^{\circ} \mathrm{C}$ for $28 \mathrm{~d}$.

\subsection{Microbiological enumeration}

Sampling of tahini or diluted tahini was conducted after $0,1,3,7,14,21$ and $28 \mathrm{~d}$ at 37,25 or $10^{\circ} \mathrm{C}$. Samples of $5 \mathrm{~mL}$ were taken by sterile syringe from each bottle and transferred into sterile stomacher bags (Seward Ltd., London, UK). The sample was mixed with $45 \mathrm{~mL}$ of $0.1 \%$ peptone water and pummeled for 2 min using a Stomacher 400 (Seward Ltd,). Then the 
homogenate was 10 -fold serially diluted in screw-capped test tubes containing $0.1 \%$ peptone water and $100 \mu \mathrm{L}$ of the diluted sample was plated onto the surface of Sorbitol MacConkey agar overlaid with TSA to allow recovery of injured cells (Osaili et al., 2010). The plates were aerobically incubated for $24 \mathrm{~h}$ at $37^{\circ} \mathrm{C}$.

\subsection{Water activity $\left(a_{w}\right)$ and $\mathrm{pH}$ measurement}

Water activity of tahini samples was measured at room temperature using an $\mathrm{a}_{\mathrm{w}}$ meter (Hygrolab, Rotronic Instr. Corp, Huntington, NY, US). The $\mathrm{pH}$ value of regular and diluted tahini was directly measured using a digital $\mathrm{pH}$ meter (Eutech model CyberScanpH1100, Singapore).

\subsection{Determination of total phenolic content}

The total phenolic content of tahini was determined using Folin-Ciocalteu spectrophotometric method as described by Osaili et al. (2017). A standard calibration curve was prepared using a stock solution of gallic acid (50 mg/50 mL). A $100 \mu \mathrm{L}$ aliquot of the sample containing phenolic compounds was added to $8.40 \mathrm{~mL}$ distilled water. Then $0.5 \mathrm{~mL}$ Folin-Ciocalteu reagent was added and agitated for 4 min using vortex mixer (Velp, Italy). The mixture was incorporated with $1 \mathrm{~mL}$ of $5 \% \mathrm{Na}_{2} \mathrm{CO}_{3}$ solution and mixed similarly. After 1 hour, the absorbance was measured at $725 \mathrm{~nm}$ using a spectrophotometer (UV 1800, $50 \mathrm{~Hz}, \mathrm{UK}$ ). The total content of phenolic compounds was calculated as milligrams of gallic acid equivalents per gram of dry matter (mg GAE/g). The analysis was conducted in triplicate.

\subsection{Statistical analysis}

The SPSS software version 19.0 (2009; IBM, Chicago, IL, US) was used to analyse the results which were represented by means \pm standard deviation (SD). The effect of time and EO concentrations on bacterial log reduction were determined by one way ANOVA. The significant differences between means of variables was determined by Duncan's post hoc test when $p$-value $<0.05$.

\section{Results and discussion}

The commercial tahini had an initial $\mathrm{pH}$ value of 6.23 and $\mathrm{a}_{\mathrm{w}}$ of 0.25 , while the initial $\mathrm{pH}$ and $\mathrm{a}_{\mathrm{w}}$ of diluted tahini were 6.31 and 0.96 , respectively. The total phenolic content in tahini was found to be $14.35 \pm 0.15 \mathrm{mg} / \mathrm{mL}$.

\subsection{Inhibitory effect of plants EOs}

The EOs of ginger, sage, radish seeds, black seeds, fir, mustard and pomegranate seeds did not exhibit any inhibitory effect against $E$. coli $\mathrm{O} 157: \mathrm{H} 7$ strains at 10 or $37^{\circ} \mathrm{C}$ (data are not shown). While the EOs of laurel leaves, lavender, cardamom, mint and rosemary exhibited moderate inhibitory effect with inhibition zones that ranged between $7.8-15.0 \mathrm{~mm}$ at $37^{\circ} \mathrm{C}$ (Table 1). The EOs of cinnamon and thyme showed the strongest inhibitory effect with inhibition zones of $24.3-50.8 \mathrm{~mm}$ at $37^{\circ} \mathrm{C}$. It was interesting that all the strains behaved similarly in response to all tested EOs at $10^{\circ} \mathrm{C}$ with no significant differences being detected among the tested strains.

Comparable results were obtained by Kon \& Rai (2012) and Prabuseenivasan et al. (2006) who reported that CO had the strongest inhibitory effect against Gram-positive and Gram-negative bacteria among 21 to 35 plant EOs. Moreover, it has been reported that cinnamon, thyme, bay leaf and garlic have significant inhibitory effects against E. coli O157:H7 (Gyawali \& Ibrahim, 2014; Dadalioğlu \& Evrendilek, 2004). In addition, the difference in the inhibitory effect of EOs may be due to the variation in the composition of bioactive compounds, which is affected by harvesting time the part of the plant which is used, as well as the extraction method (Naghdi Badi et al., 2004; Burt, 2004; Hyldgaard et al., 2012).

Since cinnamon and thyme oils exhibited the strongest in vitro inhibitory effect against E. coli O157:H7 and since no strain variations were found between the strains, E. coli O157:H7 (02:0627) was used to determine the MIC and MBC. The MICs of cinnamon and thyme oils against E. coli $\mathrm{O} 157: \mathrm{H7}$ strain $02: 0627$ were $0.10 \%$ at $37^{\circ} \mathrm{C}$ while the MBCs were $0.20 \%$ for both oils (data are not shown). These results are compatible with those reported by Oussalah et al. (2007) who indicated that Thymus vulgaris (TO) had a significant inhibitory effect against E. coli $\mathrm{O} 157: \mathrm{H7}$ at 0.05\% (v/v) and by Hammer et al. (1999) who reported that the MIC of thyme against E. coli O157:H7 was $0.12 \%(\mathrm{v} / \mathrm{v})$. On the other hand, a lower MIC for Thymus vulgaris $(0.01 \%)$ than was found in the present study against E. coli O157:H7 was reported by Hossain et al. (2013).

The mechanism responsible for the antimicrobial action of TO and $\mathrm{CO}$ is believed due to their ability to disturb the outer membrane (OM) structure of Gram-negative bacteria. As a result, small hydrophilic solutes can cross the OM through profuse

Table 1. Inhibitory effect of plant essential oils ( $20 \mu \mathrm{L} /$ disc $)$ against 3 strains of E. coli O157:H7 using disc diffusion.

\begin{tabular}{|c|c|c|c|c|c|c|c|}
\hline \multirow{2}{*}{ Foodborne pathogen } & \multicolumn{7}{|c|}{ Plant Essential oils } \\
\hline & Laurel leaves & Thyme & Lavender & Cardamon & Mint & Rosemary & Cinnamon \\
\hline \multicolumn{8}{|c|}{ a) At $10^{\circ} \mathrm{C}$ after incubation for 7 days. } \\
\hline E. coli O157:H7 02:0628 & $10.3 \pm 0.7^{\mathrm{dB}}$ & $32.7 \pm 0.5^{\mathrm{bBC}}$ & $10.3 \pm 0.5^{\mathrm{dB}}$ & $8.5 \pm 0.5^{\mathrm{eB}}$ & $10.5 \pm 0.8^{\mathrm{cE}}$ & $10.2 \pm 0.7^{\mathrm{dB}}$ & $63.2 \pm 0.7^{\mathrm{a}}$ \\
\hline E. coli $\mathrm{O} 157: \mathrm{H7}$ 02:0627 & $12.0 \pm 0.6^{\mathrm{dA}}$ & $35.7 \pm 0.5^{\mathrm{bA}}$ & $10.5 \pm 0.5^{\mathrm{dB}}$ & $8.8 \pm 0.4^{\mathrm{eB}}$ & $14.3 \pm 0.5^{\mathrm{cB}}$ & $9.0 \pm 0.8^{\mathrm{dC}}$ & $60.0 \pm 0.6^{\mathrm{aB}}$ \\
\hline \multicolumn{8}{|c|}{ b) At $37^{\circ} \mathrm{C}$ after incubation for $24 \mathrm{~h}$} \\
\hline E. coli $\mathrm{O} 157: \mathrm{H7}$ 02:0627 & $9.0 \pm 0.0^{\mathrm{eC}}$ & $29.0 \pm 4.2^{\mathrm{dB}}$ & $10.6 \pm 0.5^{\mathrm{dB}}$ & $8.3 \pm 0.5^{\mathrm{fAB}}$ & $13.8 \pm 0.4^{\mathrm{cB}}$ & $10.2 \pm 0.4^{\mathrm{deA}}$ & $39.5 \pm 0.5^{\mathrm{aC}}$ \\
\hline
\end{tabular}

Inhibition zone diameter $(\mathrm{mm})$. Values are the mean of 3 experiments $(\mathrm{n}=6) \pm$ SD. Values with same capital letters in the same row and with same small letters in the same column are not significantly different $(p \geq 0.05)$. 
porin proteins. This induces the liberation of OM-associated constituents to the external medium, and in turn these changes decrease the intracellular ATP pool of the bacterial cell, which leads to the loss of cytoplasmic membrane integrity and eventually cell death (Helander et al., 1998; Ultee et al., 1999; Oussalah et al., 2006; Boskovic et al., 2015).

\subsection{Survival of E. coli 0157:H7 in tahini and diluted tahini}

The viability of E. coli O157:H7 in tahini was decreased at all tested storage temperatures. The extent of bacterial reduction was $0.57,1.04$ and $1.15 \log _{10} \mathrm{CFU} / \mathrm{mL}$ at 10,25 and $37^{\circ} \mathrm{C}$, respectively, after $28 \mathrm{~d}$ (Table 2 ). Our results are in agreement with those reported by Al-Nabulsi et al. (2013) who indicated that the viability of E. coli O157:H7 in tahini decreased by $4.53,2.52$ and $2.18 \log _{10} \mathrm{CFU} / \mathrm{mL}$ at 37,21 and $10^{\circ} \mathrm{C}$, respectively, after $28 \mathrm{~d}$. The bacterial reduction could be partially related to the presence of phenolic compounds in tahini $(14.35 \mathrm{mg} / \mathrm{g})$ as well as to its low $\mathrm{a}_{\mathrm{w}}(0.25)$. Beside the low $\mathrm{a}_{\mathrm{w}}$ that may inhibit bacterial growth, the high fat percentage of tahini may provide protection to contaminating organisms. In addition, the $\mathrm{pH}$ of tahini $(\sim 6.8)$ is not inhibitory by itself to bacteria.

Tahini is usually consumed in a diluted form since water and other food ingredients are added to prepare different types of RTE products. In the present study, tahini was diluted 10 -fold which is the most common level of tahini used during preparation of tahini-based products. Progressive E. coli O157:H7 growth was noted in diluted tahini at all storage temperatures. The number of
E. coli $\mathrm{O} 157: \mathrm{H} 7$ cells increased by $2.15,2.74$ and $2.84 \log _{10} \mathrm{CFU} / \mathrm{mL}$ after incubation at 10,25 and $37^{\circ} \mathrm{C}$, respectively, after $28 \mathrm{~d}$ (Table 3). Similarly, Al-Nabulsi et al. (2013) reported that E. coli O157:H7 grew in 10\% diluted tahini. The neutral $\mathrm{pH}$, high $\mathrm{a}_{\mathrm{w}}$ (0.96), and nutrients availability are likely the key factors that enabled E. coli O157:H7 growth in diluted tahini. Therefore, contamination of tahini with pathogens should be treated as a microbial hazard requiring high attention because of the ability of foodborne pathogens to persist in tahini and sometimes grow, reaching the infectious dose when the $\mathrm{a}_{\mathrm{w}}$ is increased during tahini-based products preparation.

\subsection{Inhibitory effect of TO and CO on the viability of E. coli 0157:H7 in tahini and diluted tahini}

The use of plant-based materials including thyme for inactivating E. coli O157:H7 in different food products has been reported (Boskovic et al., 2015). It was notable that in the present study the extent of inactivation of $E$. coli O157:H7 in tahini increased with higher EO concentrations and higher storage temperature. The addition of TO to tahini led to a significant reduction in the viability of E. coli O157:H7 cells at all tested temperatures. After 28d, TO at concentration of $0.2,0.5,1.0$ or $2.0 \%$ caused a reduction of $1.25,1.35,1.67$ and $1.82 \log _{10} \mathrm{CFU} / \mathrm{mL}$, respectively at $37^{\circ} \mathrm{C}$ (compared to $1.15 \log _{10} \mathrm{CFU} / \mathrm{mL}$ in the control). However, the inhibitory effect of TO was reduced at lower temperatures of storage. When $0.2,0.5,1.0$ or $2.0 \%$ TO was added to tahini, a

Table 2. Effect of thyme oil on the viability of E. coli O157:H7 $\left(\log _{10} \mathrm{CFU} / \mathrm{mL}\right)$ during storage of tahini at: $10^{\circ} \mathrm{C}(\mathrm{a}), 25^{\circ} \mathrm{C}(\mathrm{b})$ and $37^{\circ} \mathrm{C}(\mathrm{c})$.

\begin{tabular}{|c|c|c|c|c|c|}
\hline \multirow{2}{*}{$\frac{\text { Time }}{\text { (Day) }}$} & \multicolumn{5}{|c|}{ Concentration of thyme oil (\%) } \\
\hline & 0.0 & 0.2 & 0.5 & 1.0 & 2.0 \\
\hline \multicolumn{6}{|c|}{ a) At $10^{\circ} \mathrm{C}$} \\
\hline $\mathbf{0}$ & $4.45 \pm 0.13^{\mathrm{aA}}$ & $4.45 \pm 0.13^{\mathrm{aA}}$ & $4.45 \pm 0.13^{\mathrm{aA}}$ & $4.45 \pm 0.13^{\mathrm{aA}}$ & $4.45 \pm 0.13^{\mathrm{aA}}$ \\
\hline 3 & $4.53 \pm 0.10^{\mathrm{aA}}$ & $4.33 \pm 0.15^{\mathrm{aA}}$ & $4.13 \pm 0.05^{\mathrm{bB}}$ & $3.85 \pm 0.12^{\mathrm{bC}}$ & $3.65 \pm 0.24^{\mathrm{bC}}$ \\
\hline 7 & $4.45 \pm 0.37^{\mathrm{aA}}$ & $4.18 \pm 0.35^{\mathrm{abA}}$ & $3.73 \pm 0.13^{\mathrm{cB}}$ & $3.45 \pm 0.10^{\mathrm{cB}}$ & $2.90 \pm 0.14^{\mathrm{cC}}$ \\
\hline 28 & $3.88 \pm 0.15^{\mathrm{bA}}$ & $3.90 \pm 0.17^{\mathrm{cdA}}$ & $3.20 \pm 0.14^{\mathrm{eB}}$ & $3.00 \pm 0.20^{\mathrm{eC}}$ & $2.80 \pm 0.08^{\mathrm{cC}}$ \\
\hline \multicolumn{6}{|c|}{ b) At $25^{\circ} \mathrm{C}$} \\
\hline $\mathbf{0}$ & $4.45 \pm 0.13^{\mathrm{aA}}$ & $4.45 \pm 0.13^{\mathrm{aA}}$ & $4.45 \pm 0.13^{\mathrm{aA}}$ & $4.45 \pm 0.13^{\mathrm{aA}}$ & $4.45 \pm 0.13^{\mathrm{aA}}$ \\
\hline 1 & $4.05 \pm 0.10^{\mathrm{bA}}$ & $3.80 \pm 0.08^{\mathrm{bB}}$ & $3.46 \pm 0.19^{\mathrm{bC}}$ & $3.20 \pm 0.08^{\mathrm{bD}}$ & $2.85 \pm 0.10^{\mathrm{bE}}$ \\
\hline 3 & $3.45 \pm 0.17^{\mathrm{cA}}$ & $3.50 \pm 0.25^{\mathrm{cA}}$ & $3.14 \pm 0.16^{\mathrm{cB}}$ & $2.83 \pm 0.10^{\mathrm{cC}}$ & $2.65 \pm 0.06^{\mathrm{bcc}}$ \\
\hline $\mathbf{0}$ & $4.45 \pm 0.13^{\mathrm{aA}}$ & $4.45 \pm 0.13^{\mathrm{aA}}$ & $4.45 \pm 0.13^{\mathrm{aA}}$ & $4.45 \pm 0.13^{\mathrm{aA}}$ & $4.45 \pm 0.13^{\mathrm{aA}}$ \\
\hline 1 & $3.85 \pm 0.06^{\mathrm{bA}}$ & $3.65 \pm 0.13^{\mathrm{bB}}$ & $3.33 \pm 0.13^{\mathrm{bC}}$ & $3.30 \pm 0.08^{\mathrm{bC}}$ & $2.56 \pm 0.17^{\mathrm{bD}}$ \\
\hline 3 & $3.03 \pm 0.15^{\mathrm{dA}}$ & $2.93 \pm 0.30^{\mathrm{dA}}$ & $2.95 \pm 0.50^{\mathrm{bA}}$ & $2.28 \pm 0.19^{\mathrm{dB}}$ & $2.10 \pm 0.14^{\mathrm{cdB}}$ \\
\hline 7 & $3.23 \pm 0.10^{\mathrm{cdA}}$ & $3.15 \pm 0.05^{\mathrm{cdAB}}$ & $3.08 \pm 0.05^{\mathrm{bB}}$ & $2.88 \pm 0.10^{c \mathrm{C}}$ & $2.58 \pm 0.05^{\mathrm{bD}}$ \\
\hline 14 & $3.33 \pm 0.30^{\mathrm{cA}}$ & $2.40 \pm 0.08^{\mathrm{eB}}$ & $2.35 \pm 0.26^{\mathrm{cB}}$ & $2.09 \pm 0.38^{\mathrm{dB}}$ & $2.03 \pm 0.30^{\mathrm{dB}}$ \\
\hline 21 & $3.24 \pm 0.20^{\mathrm{cdA}}$ & $3.51 \pm 0.13^{\mathrm{bAB}}$ & $2.99 \pm 0.20^{\mathrm{bB}}$ & $2.29 \pm 0.35^{\mathrm{dC}}$ & $2.35 \pm 0.20^{\mathrm{bcc}}$ \\
\hline 28 & $3.30 \pm 0.10^{\mathrm{cdA}}$ & $3.20 \pm 0.10^{\mathrm{cA}}$ & $3.10 \pm 0.14^{\mathrm{bA}}$ & $2.78 \pm 0.13^{\mathrm{cB}}$ & $2.63 \pm 0.10^{\mathrm{bB}}$ \\
\hline
\end{tabular}

Values are the means of 2 experiments $(n=4) \pm S D$; Values with same capital letters in the same row and with same small letters in the same column are not significantly different ( $p \geq 0.05)$. 
Al-Nabulsi et al.

Table 3. Effect of thyme oil on the viability of E. coli O157:H7 $\left(\log _{10} \mathrm{CFU} / \mathrm{mL}\right)$ during storage of diluted tahini at:10 ${ }^{\circ} \mathrm{C}(\mathrm{a}), 25^{\circ} \mathrm{C}(\mathrm{b})$ and $37^{\circ} \mathrm{C}(\mathrm{c})$.

\begin{tabular}{|c|c|c|c|c|c|}
\hline \multirow{2}{*}{$\begin{array}{l}\text { Time } \\
\text { (Day) }\end{array}$} & \multicolumn{5}{|c|}{ Concentration of thyme oil (\%) } \\
\hline & 0.0 & 0.2 & 0.5 & 1.0 & 2.0 \\
\hline \multicolumn{6}{|c|}{ a) At $10^{\circ} \mathrm{C}$} \\
\hline $\mathbf{0}$ & $5.10 \pm 0.00^{\mathrm{cA}}$ & $5.10 \pm 0.00^{\mathrm{bA}}$ & $5.10 \pm 0.00^{\mathrm{cA}}$ & $5.10 \pm 0.00^{\mathrm{aA}}$ & $5.10 \pm 0.00^{\mathrm{aA}}$ \\
\hline 1 & $5.75 \pm 0.85^{\mathrm{bA}}$ & $5.30 \pm 0.06^{\mathrm{aA}}$ & $4.97 \pm 0.51^{\mathrm{cAB}}$ & $4.38 \pm 0.30^{\mathrm{bC}}$ & $3.56 \pm 0.48^{\mathrm{cC}}$ \\
\hline 3 & $6.86 \pm 0.28^{\mathrm{aA}}$ & $6.97 \pm 0.08^{\mathrm{aA}}$ & $6.90 \pm 0.24^{\mathrm{aA}}$ & $4.15 \pm 0.13^{\mathrm{cB}}$ & $3.38 \pm 0.30^{\mathrm{cC}}$ \\
\hline 7 & $7.28 \pm 0.15^{\mathrm{aA}}$ & $7.06 \pm 0.19^{\mathrm{aA}}$ & $6.06 \pm 0.21^{\mathrm{bB}}$ & $4.92 \pm 0.17^{\mathrm{bC}}$ & $4.33 \pm 0.54^{\mathrm{bD}}$ \\
\hline 14 & $7.15 \pm 0.17^{\mathrm{aA}}$ & $6.66 \pm 0.20^{\mathrm{aB}}$ & $5.30 \pm 0.46^{\mathrm{bcc}}$ & $4.14 \pm 0.18^{\mathrm{cD}}$ & $3.31 \pm 0.19^{\mathrm{cE}}$ \\
\hline 21 & $7.10 \pm 0.23^{\mathrm{aA}}$ & $6.94 \pm 0.27^{\mathrm{aA}}$ & $6.55 \pm 0.28^{\mathrm{aA}}$ & $3.06 \pm 0.96^{\mathrm{dB}}$ & $2.88 \pm 1.03^{\mathrm{cB}}$ \\
\hline 28 & $7.25 \pm 0.25^{\mathrm{aA}}$ & $6.98 \pm 0.17^{\mathrm{aA}}$ & $6.98 \pm 0.19^{\mathrm{aA}}$ & $2.26 \pm 0.15^{\mathrm{eB}}$ & $2.08 \pm 0.15^{\mathrm{dB}}$ \\
\hline \multicolumn{6}{|c|}{ b) At $25^{\circ} \mathrm{C}$} \\
\hline $\mathbf{0}$ & $5.10 \pm 0.00^{\mathrm{cA}}$ & $5.10 \pm 0.00^{\mathrm{bA}}$ & $5.10 \pm 0.00^{\mathrm{cA}}$ & $5.10 \pm 0.00^{\mathrm{aA}}$ & $5.10 \pm 0.00^{\mathrm{aA}}$ \\
\hline 1 & $7.20 \pm 0.19^{\mathrm{cA}}$ & $6.73 \pm 0.20^{\mathrm{aB}}$ & $6.63 \pm 0.24^{\mathrm{aB}}$ & $6.18 \pm 0.16^{\mathrm{aC}}$ & $4.85 \pm 0.30^{\mathrm{aD}}$ \\
\hline 3 & $7.35 \pm 0.10^{\mathrm{bcA}}$ & $7.09 \pm 0.90^{\mathrm{aAB}}$ & $6.85 \pm 0.13^{\mathrm{aB}}$ & $6.24 \pm 0.05^{\mathrm{aC}}$ & $4.95 \pm 0.29^{\mathrm{aD}}$ \\
\hline 7 & $7.33 \pm 0.06^{\mathrm{bcA}}$ & $6.88 \pm 0.32^{\mathrm{aB}}$ & $5.86 \pm 0.16^{\mathrm{bC}}$ & $5.40 \pm 0.36^{\mathrm{bD}}$ & $4.40 \pm 0.14^{\mathrm{bD}}$ \\
\hline 14 & $7.42 \pm 0.06^{\mathrm{bA}}$ & $5.88 \pm 0.20^{\mathrm{bB}}$ & $5.92 \pm 0.25^{\mathrm{bB}}$ & $4.28 \pm 0.51^{\mathrm{cC}}$ & $2.18 \pm 0.21^{\mathrm{cD}}$ \\
\hline 21 & $7.48 \pm 0.12^{\mathrm{bA}}$ & $5.87 \pm 0.73^{\mathrm{bB}}$ & $4.67 \pm 0.13^{\mathrm{dC}}$ & $2.62 \pm 0.37^{\mathrm{dD}}$ & $2.06 \pm 0.16^{\mathrm{cD}}$ \\
\hline 28 & $7.84 \pm 0.07^{\mathrm{aA}}$ & $4.87 \pm 0.49^{\mathrm{cB}}$ & $3.94 \pm 0.42^{\mathrm{eC}}$ & $\mathrm{ND}^{\mathrm{eD} *}$ & $\mathrm{ND}^{\mathrm{dD}}$ \\
\hline \multicolumn{6}{|c|}{ c) At $37^{\circ} \mathrm{C}$} \\
\hline $\mathbf{0}$ & $5.10 \pm 0.00^{\mathrm{cA}}$ & $5.10 \pm 0.00^{\mathrm{bA}}$ & $5.10 \pm 0.00^{\mathrm{cA}}$ & $5.10 \pm 0.00^{\mathrm{aA}}$ & $5.10 \pm 0.00^{\mathrm{aA}}$ \\
\hline 1 & $6.80 \pm 0.20^{\operatorname{cd} A}$ & $6.90 \pm 0.10^{\mathrm{aA}}$ & $6.57 \pm 0.15^{\mathrm{aB}}$ & $6.26 \pm 0.35^{\mathrm{aC}}$ & $4.89 \pm 0.10^{\mathrm{bD}}$ \\
\hline 3 & $6.70 \pm 0.50^{\mathrm{dA}}$ & $6.42 \pm 0.15^{\mathrm{aA}}$ & $6.00 \pm 0.20^{\mathrm{bB}}$ & $5.83 \pm 0.20^{\mathrm{bB}}$ & $5.90 \pm 0.11^{\mathrm{aB}}$ \\
\hline 7 & $7.03 \pm 0.19^{\mathrm{bcA}}$ & $5.14 \pm 0.60^{\mathrm{bB}}$ & $3.98 \pm 0.21^{\mathrm{dC}}$ & $3.54 \pm 0.31^{\mathrm{dC}}$ & $2.90 \pm 0.30^{\mathrm{cD}}$ \\
\hline 14 & $7.18 \pm 0.25^{\mathrm{bA}}$ & $4.58 \pm 0.68^{\mathrm{cB}}$ & $3.58 \pm 0.12^{\mathrm{eC}}$ & $2.54 \pm 0.47^{\mathrm{eD}}$ & $2.20 \pm 0.23^{\mathrm{dD}}$ \\
\hline 21 & $7.05 \pm 0.17^{\mathrm{bcA}}$ & $2.67 \pm 0.22^{\mathrm{dB}}$ & $2.57 \pm 0.17^{\mathrm{fB}}$ & $2.08 \pm 0.15^{\mathrm{fC}}$ & $1.93 \pm 0.15^{\mathrm{eC}}$ \\
\hline 28 & $7.94 \pm 0.14^{\mathrm{aA}}$ & $2.52 \pm 0.17^{\mathrm{dB}}$ & $\mathrm{ND}^{\mathrm{gC}}$ & $\mathrm{ND}^{\mathrm{gC}}$ & $\mathrm{ND}^{\mathrm{fC}}$ \\
\hline
\end{tabular}

${ }^{*} \mathrm{ND}$ : Cells of $E$. coli $\mathrm{O} 157: \mathrm{H} 7$ were not detected $(<1 \mathrm{CFU} / \mathrm{mL})$. Values are the means of 2 experiments $(\mathrm{n}=4) \pm \mathrm{SD}$. Values with same capital letters in the same row and with same small letters in the same column are not significantly different $(p \geq 0.05)$.

$1.45,1.55,1.40$ and $2.01 \log _{10} \mathrm{CFU} / \mathrm{mL}$ reduction in the number of $E$. coli $\mathrm{O} 157: \mathrm{H7}$ cells, respectively, was noted compared to $1.04 \log _{10} \mathrm{CFU} / \mathrm{mL}$ in the control at $25^{\circ} \mathrm{C}$ after $28 \mathrm{~d}$. At $10^{\circ} \mathrm{C}$, the reduction was $0.55,1.25,1.45$ and $1.65 \log _{10} \mathrm{CFU} / \mathrm{mL}$, respectively, with samples treated with $0.2,0.5,1.0$ or $2.0 \%$ TO compared to $0.57 \log _{10} \mathrm{CFU} / \mathrm{mL} 10^{\circ} \mathrm{C}$ in the control samples (Table 2).

In diluted tahini after $28 \mathrm{~d}$ storage, $\mathrm{TO}$ at $0.5 \%$ or $1.0 \%$ caused a complete reduction in the numbers of $E$. coli O157:H7 at 37 or $25^{\circ} \mathrm{C}$, respectively. At $10^{\circ} \mathrm{C}$, E. coli O157: $\mathrm{H} 7$ cells showed more resistance to TO since a $3.02 \log _{10} \mathrm{CFU} / \mathrm{mL}$ reduction was observed after $28 \mathrm{~d}$ compared to the initial inoculation level in samples treated with $2.0 \%$ TO (Table 3). Burt \& Reinders (2003) reported that bacteriostatic action of TO against E. coli O157:H7 occurred at $0.12 \%$, while a bactericidal effect was noted at $0.25 \%$. Likewise, Solomakos et al. (2008) investigated the antimicrobial effect of $0.3 \%, 0.6 \%$, or $0.9 \%$ TO against E. coli $\mathrm{O} 157: \mathrm{H} 7$ in minced beef and found that $0.6 \%$ thyme oil inhibited its growth during storage at $10^{\circ} \mathrm{C}$.

$\mathrm{CO}$ reduced the viable numbers of $E$. coli $\mathrm{O} 157: \mathrm{H} 7$ by $1.23,1.42,1.72$ and $2.20 \log _{10} \mathrm{CFU} / \mathrm{mL}$ in tahini with $0.2,0.5,1.0$ or $2.0 \% \mathrm{CO}$, respectively, at $37^{\circ} \mathrm{C}$ after $28 \mathrm{~d}$, compared to $1.2 \log _{10} \mathrm{CFU} / \mathrm{mL}$ in the control samples. At $25^{\circ} \mathrm{C}$, the bacterial reduction was $0.95,1.06,1.44$ and $1.79 \log _{10} \mathrm{CFU} / \mathrm{mL}$ by addition of $0.2,0.5,1.0$ or $2.0 \%$ CO respectively, compared to $0.90 \log _{10}$ $\mathrm{CFU} / \mathrm{mL}$ in the control after $28 \mathrm{~d}$. At $10^{\circ} \mathrm{C}$, numbers of $\mathrm{E}$. coli O157:H7 were reduced by $0.80,0.95,1.25$ and $1.38 \log _{10} \mathrm{CFU} / \mathrm{mL}$ by addition of $0.2,0.5,1.0$ or $2.0 \% \mathrm{CO}$ to tahini, respectively, compared to $0.47 \log _{10} \mathrm{CFU} / \mathrm{mL}$ at $10^{\circ} \mathrm{C}$ in the control (Table 4). In contrast to its activity in tahini, $\mathrm{CO}$ was more inhibitory in diluted tahini. At $10{ }^{\circ} \mathrm{C}$, E. coli $\mathrm{O} 157: \mathrm{H} 7$ cells were not detectable when 1.0 or $2.0 \%$ was used after $21 \mathrm{~d}$. Nonetheless, at 25 and $37^{\circ} \mathrm{C}$, the antibacterial activity of $\mathrm{CO}$ was more obvious where E. coli O157:H7 cells were not detected after 14d when $0.5 \%$ was used (Table 5 ).

CO showed significant inhibitory effect against E. coli O157:H7 in both commercial and diluted tahini. However, its activity was higher than $\mathrm{TO}$ in diluted tahini where $0.5 \% \mathrm{CO}$ prevented E. coli O157: $\mathrm{H} 7$ detection after $14 \mathrm{~d}$ at 25 and $37^{\circ} \mathrm{C}$. Olaimat et al. (2019) also indicated that $\mathrm{CO}$ had higher antimicrobial activity than TO against Salmonella enterica in hummus. Similarly, Ceylan et al. (2004) reported that $0.3 \%$ CO reduced numbers of E. coli O157:H7 in apple juice by 1.6 and $2.0 \log _{10} \mathrm{CFU} / \mathrm{mL}$ at 8 and $25^{\circ} \mathrm{C}$, respectively.

In diluted tahini, the addition of $\mathrm{TO}$ or $\mathrm{CO}$ resulted in more inhibitory activity compared to regular tahini and caused significant 
Table 4. Effect of cinnamon oil on the viability of E. coli O157:H7 $\left(\log _{10} \mathrm{CFU} / \mathrm{mL}\right)$ during storage of tahini at: $10^{\circ} \mathrm{C}(\mathrm{a}), 25^{\circ} \mathrm{C}(\mathrm{b})$ and $37^{\circ} \mathrm{C}(\mathrm{c})$.

\begin{tabular}{|c|c|c|c|c|c|}
\hline \multirow{2}{*}{$\frac{\text { Time }}{\text { (Day) }}$} & \multicolumn{5}{|c|}{ Concentration of cinnamon oil (\%) } \\
\hline & 0.0 & 0.2 & 0.5 & 1.0 & 2.0 \\
\hline \multicolumn{6}{|c|}{ a) At $10^{\circ} \mathrm{C}$} \\
\hline $\mathbf{0}$ & $4.70 \pm 0.07^{\mathrm{aA}}$ & $4.70 \pm 0.07^{\mathrm{aA}}$ & $4.70 \pm 0.07^{\mathrm{aA}}$ & $4.70 \pm 0.07^{\mathrm{bA}}$ & $4.70 \pm 0.07^{\mathrm{aA}}$ \\
\hline 1 & $4.73 \pm 0.05^{\mathrm{aA}}$ & $4.69 \pm 0.06^{\mathrm{aA}}$ & $4.54 \pm 0.06^{\mathrm{bB}}$ & $4.54 \pm 0.08^{\mathrm{cB}}$ & $4.08 \pm 0.09^{\mathrm{bC}}$ \\
\hline 3 & $4.75 \pm 0.04^{\mathrm{aA}}$ & $4.77 \pm 0.04^{\mathrm{aA}}$ & $4.70 \pm 0.07^{\mathrm{aA}}$ & $4.30 \pm 0.12^{\mathrm{cB}}$ & $3.80 \pm 0.01^{\mathrm{cC}}$ \\
\hline 7 & $4.48 \pm 0.08^{\mathrm{bA}}$ & $4.40 \pm 0.12^{\mathrm{bA}}$ & $4.40 \pm 0.09^{\mathrm{cA}}$ & $4.16 \pm 0.04^{\mathrm{dB}}$ & $3.80 \pm 0.07^{\mathrm{cC}}$ \\
\hline 14 & $4.40 \pm 0.07^{\mathrm{bA}}$ & $4.39 \pm 0.06^{\mathrm{bA}}$ & $4.22 \pm 0.07^{\mathrm{dA}}$ & $3.99 \pm 0.08^{\mathrm{eB}}$ & $3.84 \pm 0.10^{c \mathrm{C}}$ \\
\hline 21 & $4.50 \pm 0.07^{\mathrm{bA}}$ & $4.30 \pm 0.07^{\mathrm{bB}}$ & $4.09 \pm 0.12^{\mathrm{dC}}$ & $3.66 \pm 0.06^{\mathrm{eD}}$ & $3.45 \pm 0.11^{\mathrm{dE}}$ \\
\hline 28 & $4.23 \pm 0.13^{\mathrm{cA}}$ & $3.90 \pm 0.16^{\mathrm{cB}}$ & $3.75 \pm 0.05^{\mathrm{cB}}$ & $3.45 \pm 0.09^{\mathrm{fC}}$ & $3.32 \pm 0.08^{\mathrm{dc}}$ \\
\hline \multicolumn{6}{|c|}{ b) At $25^{\circ} \mathrm{C}$} \\
\hline $\mathbf{0}$ & $4.70 \pm 0.07^{\mathrm{aA}}$ & $4.70 \pm 0.07^{\mathrm{aA}}$ & $4.70 \pm 0.07^{\mathrm{aA}}$ & $4.70 \pm 0.07^{\mathrm{bA}}$ & $4.70 \pm 0.07^{\mathrm{aA}}$ \\
\hline 1 & $4.71 \pm 0.07^{\mathrm{aA}}$ & $4.60 \pm 0.07^{\mathrm{aA}}$ & $4.40 \pm 0.07^{\mathrm{bB}}$ & $4.35 \pm 0.06^{\mathrm{bB}}$ & $3.87 \pm 0.07^{\mathrm{bC}}$ \\
\hline 3 & $4.75 \pm 0.09^{\mathrm{aA}}$ & $4.38 \pm 0.04^{\mathrm{bB}}$ & $4.13 \pm 0.08^{\mathrm{cC}}$ & $4.08 \pm 0.80^{c \mathrm{C}}$ & $3.81 \pm 0.02^{\mathrm{bD}}$ \\
\hline 7 & $4.64 \pm 0.04^{\mathrm{aA}}$ & $4.30 \pm 0.07^{\mathrm{bcB}}$ & $4.35 \pm 0.05^{\mathrm{bB}}$ & $4.03 \pm 0.04^{\mathrm{cC}}$ & $3.90 \pm 0.12^{\mathrm{bC}}$ \\
\hline 14 & $4.33 \pm 0.11^{\mathrm{bA}}$ & $4.25 \pm 0.06^{\mathrm{cA}}$ & $3.93 \pm 0.04^{\mathrm{dB}}$ & $3.70 \pm 0.01^{\mathrm{dC}}$ & $3.58 \pm 0.08^{\mathrm{cC}}$ \\
\hline 21 & $3.86 \pm 0.06^{\mathrm{dAB}}$ & $3.95 \pm 0.11^{\mathrm{dA}}$ & $3.80 \pm 0.07^{\mathrm{eB}}$ & $3.38 \pm 0.08^{\mathrm{eC}}$ & $3.30 \pm 0.06^{\mathrm{dC}}$ \\
\hline 28 & $3.79 \pm 0.07^{\mathrm{dA}}$ & $3.75 \pm 0.05^{\mathrm{eAB}}$ & $3.64 \pm 0.08^{\mathrm{fB}}$ & $3.26 \pm 0.06^{\mathrm{fC}}$ & $2.91 \pm 0.14^{\mathrm{eD}}$ \\
\hline \multicolumn{6}{|c|}{ c) At $37^{\circ} \mathrm{C}$} \\
\hline $\mathbf{0}$ & $4.70 \pm 0.07^{\mathrm{aA}}$ & $4.70 \pm 0.07^{\mathrm{aA}}$ & $4.70 \pm 0.07^{\mathrm{aA}}$ & $4.70 \pm 0.07^{\mathrm{bA}}$ & $4.70 \pm 0.07^{\mathrm{aA}}$ \\
\hline 1 & $4.64 \pm 0.05^{\mathrm{aAB}}$ & $4.67 \pm 0.10^{\mathrm{aA}}$ & $4.54 \pm 0.04^{\mathrm{bB}}$ & $4.11 \pm 0.07^{\mathrm{bC}}$ & $4.08 \pm 0.08^{\mathrm{bC}}$ \\
\hline 3 & $4.23 \pm 0.08^{\mathrm{bA}}$ & $4.12 \pm 0.12^{\mathrm{bAB}}$ & $4.07 \pm 0.50^{\mathrm{cBC}}$ & $3.95 \pm 0.05^{\mathrm{cC}}$ & $3.69 \pm 0.06^{\mathrm{CD}}$ \\
\hline 7 & $3.93 \pm 0.08^{\mathrm{cA}}$ & $3.80 \pm 0.12^{\mathrm{cA}}$ & $3.63 \pm 0.08^{\mathrm{dB}}$ & $3.53 \pm 0.08^{\mathrm{dB}}$ & $3.07 \pm 0.09^{\mathrm{dc}}$ \\
\hline 14 & $3.62 \pm 0.04^{\mathrm{dA}}$ & $3.58 \pm 0.04^{\mathrm{dA}}$ & $3.40 \pm 0.12^{\mathrm{eB}}$ & $3.30 \pm 0.07^{\mathrm{eB}}$ & $3.05 \pm 0.09^{\mathrm{dC}}$ \\
\hline 21 & $3.59 \pm 0.11^{\mathrm{dA}}$ & $3.55 \pm 0.12^{\mathrm{dA}}$ & $3.38 \pm 0.08^{\mathrm{eB}}$ & $3.16 \pm 0.07^{\mathrm{eC}}$ & $2.53 \pm 0.08^{\mathrm{eD}}$ \\
\hline 28 & $3.50 \pm 0.07^{\mathrm{dA}}$ & $3.47 \pm 0.04^{\mathrm{dA}}$ & $3.28 \pm 0.08^{\mathrm{eB}}$ & $2.98 \pm 0.08^{\mathrm{fC}}$ & $2.50 \pm 0.10^{\mathrm{eD}}$ \\
\hline
\end{tabular}

Values are the means of 2 experiments $(n=4) \pm S D$. Values with same capital letters in the same row and with same small letters in the same column are not significantly different $(p \geq 0.05)$.

reductions in E. coli O157:H7 numbers which reached below the detection level. This could have been due to lower levels of fat in diluted tahini after being diluted 10-fold with water. Similarly, it was reported that $\mathrm{CO}$ at a concentration of $0.5 \%$ in full fat cheese reduced numbers of $S$. Enteritidis by $0.3 \log _{10} \mathrm{CFU} / \mathrm{mL}$ at the first day, compared to $3.1 \log _{10} \mathrm{CFU} / \mathrm{mL}$ in the low fat cheese (Smith-Palmer et al., 2001). EOs are more soluble in the fat phase compared to the aqueous phase; however, the proliferation of organisms usually occurs in the aqueous phase, which may reduce the effectiveness of TO and CO (Burt, 2004).

EO concentration and temperature are major factors that affect the inhibitory action of TO and $\mathrm{CO}$ in undiluted and diluted tahini. The antibacterial activity was significantly increased as the storage temperature increased $\left(37>25>10^{\circ} \mathrm{C}\right)$. The results in the present study are in agreement with previous findings on the activity of TO and CO against pathogenic bacteria. It was reported that the addition of cinnamaldehyde to apple juice reduced E. coli O157:H7 cells to undetectable levels after 5 and $14 \mathrm{~d}$ at 23 and $4{ }^{\circ} \mathrm{C}$, respectively (Baskaran et al., 2010). Additionally, combination of $\mathrm{CO}$ with nisin induced greater inhibitory effect against $E$. coli O157:H7 cells in apple juice at $20^{\circ} \mathrm{C}$ compared to $5{ }^{\circ} \mathrm{C}$ (Yuste \& Fung, 2004).

Considering that the TO and CO mainly damage the cytoplasmic membrane of bacteria, altered permeability of the membrane may affect the passive transport of hydrophobic particles and influence protein-protein interactions (Zhang \& Rock, 2008). In addition at lower temperatures, permeability of the bacterial membrane is reduced when higher proportions of saturated fatty acids are contained in the membrane and thus decrease the inhibitory activity of EOs (Al-Nabulsi \& Holley, 2006; Mani-Lopez et al., 2012).

Although EOs showed substantial inhibitory effects against foodborne pathogens, the presence of a number of ingredients in foods including fat, proteins, carbohydrates, salt, water, preservatives, antioxidants, and some additives may reduce the inhibitory activity of EOs (Perricone et al., 2015). Moreover, another limitation of using EOs as preservatives is their negative impact on flavor since high concentrations are required to achieve satisfactory antimicrobial activity (Al-Nabulsi et al., 2020; Olaimat et al., 2019). This limitation could be circumvented by using lower concentrations of the EOs along with other barriers (e.g low storage temperature, mild heating of the product, or in combination with organic acids) as part of the hurdle technology. Additionally, further research is needed to study the potential of incorporating EOs such as TO and $\mathrm{CO}$ in the packaging material used to pack tahini, and to study the effect of such an active package on the viability of pathogens in tahini. 
Table 5. Effect of cinnamon oil on the viability of E. coli $\mathrm{O} 157: \mathrm{H} 7\left(\log _{10} \mathrm{CFU} / \mathrm{mL}\right)$ during storage of diluted tahini at: $10{ }^{\circ} \mathrm{C}(\mathrm{a}), 25^{\circ} \mathrm{C}(\mathrm{b})$, and $37^{\circ} \mathrm{C}(\mathrm{c})$.

\begin{tabular}{|c|c|c|c|c|c|}
\hline \multirow{2}{*}{$\begin{array}{l}\text { Time } \\
\text { (Day) }\end{array}$} & \multicolumn{5}{|c|}{ Concentration of cinnamon oil (\%) } \\
\hline & 0.0 & 0.2 & 0.5 & 1.0 & 2.0 \\
\hline \multicolumn{6}{|c|}{ a) At $10^{\circ} \mathrm{C}$} \\
\hline $\mathbf{0}$ & $4.65 \pm 0.09^{\mathrm{eA}}$ & $4.65 \pm 0.09^{\mathrm{aA}}$ & $4.65 \pm 0.09^{\mathrm{aA}}$ & $4.65 \pm 0.09^{\mathrm{aA}}$ & $4.65 \pm 0.09^{\mathrm{aA}}$ \\
\hline 1 & $6.49 \pm 0.12^{\mathrm{dA}}$ & $4.89 \pm 0.07^{\mathrm{aB}}$ & $4.51 \pm 0.01^{\mathrm{aC}}$ & $4.23 \pm 0.08^{\mathrm{bD}}$ & $4.15 \pm 0.11^{\mathrm{bD}}$ \\
\hline 3 & $6.17 \pm 0.10^{\mathrm{cA}}$ & $4.55 \pm 0.03^{\text {bB }}$ & $4.47 \pm 0.11^{\mathrm{aB}}$ & $3.99 \pm 0.09^{\mathrm{cC}}$ & $3.15 \pm 0.15^{\mathrm{cD}}$ \\
\hline 7 & $7.03 \pm 0.14^{\mathrm{bA}}$ & $4.60 \pm 0.19^{\mathrm{abB}}$ & $4.03 \pm 0.11^{\mathrm{bC}}$ & $3.33 \pm 0.08^{\mathrm{dD}}$ & $2.40 \pm 0.29^{\mathrm{dE}}$ \\
\hline 14 & $7.27 \pm 0.04^{\mathrm{aA}}$ & $4.14 \pm 0.15^{\mathrm{cB}}$ & $2.84 \pm 0.07^{\mathrm{cC}}$ & $1.88 \pm 0.13^{\mathrm{eD}}$ & $\mathrm{ND}^{\mathrm{eE} *}$ \\
\hline 21 & $7.27 \pm 0.11^{\mathrm{aA}}$ & $3.81 \pm 0.08^{\mathrm{dB}}$ & $2.42 \pm 0.17^{\mathrm{dC}}$ & $\mathrm{ND}^{\mathrm{fD}}$ & $\mathrm{ND}^{\mathrm{eD}}$ \\
\hline 28 & $7.35 \pm 0.04^{\mathrm{aA}}$ & $3.58 \pm 0.25^{\mathrm{dB}}$ & $2.05 \pm 0.21^{\mathrm{eC}}$ & $\mathrm{ND}^{\mathrm{fD}}$ & $\mathrm{ND}^{\mathrm{eD}}$ \\
\hline \multicolumn{6}{|c|}{ b) At $25^{\circ} \mathrm{C}$} \\
\hline $\mathbf{0}$ & $4.65 \pm 0.09^{\mathrm{eA}}$ & $4.65 \pm 0.09^{\mathrm{aA}}$ & $4.65 \pm 0.09^{\mathrm{aA}}$ & $4.65 \pm 0.09^{\mathrm{aA}}$ & $4.65 \pm 0.09^{\mathrm{aA}}$ \\
\hline 1 & $5.68 \pm 0.11^{\mathrm{dB}}$ & $6.44 \pm 0.07^{\mathrm{aA}}$ & $5.23 \pm 0.08^{\mathrm{aC}}$ & $3.73 \pm 0.20^{\mathrm{bD}}$ & $3.35 \pm 0.09^{\mathrm{bE}}$ \\
\hline 3 & $6.72 \pm 0.09^{\mathrm{cA}}$ & $6.00 \pm 0.13^{\mathrm{bB}}$ & $4.51 \pm 0.18^{\mathrm{bC}}$ & $3.43 \pm 0.04^{\mathrm{cD}}$ & $3.28 \pm 0.08^{\mathrm{bD}}$ \\
\hline 7 & $7.36 \pm 0.08^{\mathrm{bA}}$ & $5.39 \pm 0.09^{\mathrm{cB}}$ & $3.02 \pm 0.10^{\mathrm{cC}}$ & $2.88 \pm 0.29^{\mathrm{dC}}$ & $2.04 \pm 0.34^{\mathrm{cE}}$ \\
\hline 14 & $7.19 \pm 0.11^{\mathrm{bA}}$ & $5.05 \pm 0.11^{\mathrm{dB}}$ & $\mathrm{ND}^{\mathrm{dC}}$ & $\mathrm{ND}^{\mathrm{eC}}$ & $\mathrm{ND}^{\mathrm{dC}}$ \\
\hline 21 & $7.29 \pm 0.11^{\mathrm{abA}}$ & $4.69 \pm 0.07^{\mathrm{eB}}$ & $\mathrm{ND}^{\mathrm{dC}}$ & $\mathrm{ND}^{\mathrm{eC}}$ & $\mathrm{ND}^{\mathrm{Dc}}$ \\
\hline 28 & $7.25 \pm 0.04^{\mathrm{aA}}$ & $3.42 \pm 0.08^{\mathrm{efB}}$ & $\mathrm{ND}^{\mathrm{dC}}$ & $\mathrm{ND}^{\mathrm{eC}}$ & $\mathrm{ND}^{\mathrm{dC}}$ \\
\hline \multicolumn{6}{|c|}{ c) At $37^{\circ} \mathrm{C}$} \\
\hline 0 & $4.65 \pm 0.09^{\mathrm{eA}}$ & $4.65 \pm 0.09^{\mathrm{aA}}$ & $4.65 \pm 0.09^{\mathrm{aA}}$ & $4.65 \pm 0.09^{\mathrm{aA}}$ & $4.65 \pm 0.09^{\mathrm{aA}}$ \\
\hline 1 & $6.71 \pm 0.07^{\mathrm{dA}}$ & $6.68 \pm 0.12^{\mathrm{aA}}$ & $4.36 \pm 0.04^{\mathrm{bB}}$ & $4.20 \pm 0.10^{\mathrm{bC}}$ & $3.99 \pm 0.05^{\mathrm{bD}}$ \\
\hline 3 & $6.88 \pm 0.08^{\mathrm{dA}}$ & $5.06 \pm 0.18^{\mathrm{bB}}$ & $4.17 \pm 0.40^{\mathrm{cC}}$ & $3.50 \pm 0.20^{\mathrm{cD}}$ & $2.25 \pm 0.11^{\mathrm{cE}}$ \\
\hline 7 & $7.19 \pm 0.12^{\mathrm{dA}}$ & $4.94 \pm 0.10^{\mathrm{bcB}}$ & $2.75 \pm 0.08^{\mathrm{dC}}$ & $2.75 \pm 0.22^{\mathrm{dC}}$ & $\mathrm{ND}^{\mathrm{eD}}$ \\
\hline 14 & $7.39 \pm 0.09^{\mathrm{cA}}$ & $4.82 \pm 0.13^{\mathrm{cdB}}$ & $\mathrm{ND}^{\mathrm{eC}}$ & $\mathrm{ND}^{\mathrm{eC}}$ & $\mathrm{ND}^{\mathrm{eC}}$ \\
\hline 21 & $7.66 \pm 0.15^{\mathrm{bA}}$ & $4.75 \pm 0.09^{\mathrm{cdB}}$ & $\mathrm{ND}^{\mathrm{eC}}$ & $\mathrm{ND}^{\mathrm{eC}}$ & $\mathrm{ND}^{\mathrm{eC}}$ \\
\hline 28 & $8.00 \pm 0.20^{\mathrm{aA}}$ & $3.41 \pm 0.09^{\mathrm{eB}}$ & $\mathrm{ND}^{\mathrm{eC}}$ & $\mathrm{ND}^{\mathrm{eC}}$ & $\mathrm{ND}^{\mathrm{eC}}$ \\
\hline
\end{tabular}

${ }^{*} \mathrm{ND}$ : Cells of $E$. coli O157:H7 were not detected $(<1 \mathrm{CFU} / \mathrm{mL})$. Values are the means of 2 experiments $(\mathrm{n}=4) \pm \mathrm{SD}$. Values with same capital letters in the same row and with same small letters in the same column are not significantly different $(p \geq 0.05)$.

\section{Conclusion}

The current study reports the results of using 14 different essential oils against E. coli O157:H7 in tahini and diluted tahini. TO and $\mathrm{CO}$ exhibited the strongest antibacterial activity against E. coli $\mathrm{O} 157: \mathrm{H} 7$ with a range of inhibition zones from 33.0 to $50.8 \mathrm{~mm}$. In spite of the fact that tahini did not enhance the growth of E. coli O157:H7, the pathogen was able to survive in tahini for up to $28 \mathrm{~d}$. Nonetheless, diluted tahini permitted enhanced growth $(p \leq 0.05)$ of E. coli O157:H7 at all incubation temperatures. The addition of TO or $\mathrm{CO}$ at $\leq 2.0 \%$ is recommended for use by processors of tahini or tahini-based products to inhibit the growth of $\mathrm{E}$. coli $\mathrm{O} 157: \mathrm{H} 7$ when stored over a wide temperature range $\left(10\right.$ to $\left.37^{\circ} \mathrm{C}\right)$.

\section{Acknowledgements}

The authors thank the Deanship of Scientific Research at Jordan University of Science and Technology for funding the project (Project \# 134/2016).

\section{References}

Abu-Jdayil, B., Al-Malah, K., \& Asoud, H. (2002). Rheological characterization of milled sesame (tahineh). Food Hydrocolloids, 16(1), 55-61. http://dx.doi.org/10.1016/S0268-005X(01)00040-6.
Al-Nabulsi, A. A., \& Holley, R. A. (2006). Enhancing the antimicrobial effects of bovine lactoferrin against Escherichia coli O157:H7 by cation chelation, $\mathrm{NaCl}$ and temperature. Journal of Applied Microbiology, 100(2), 244-255.

Al-Nabulsi, A. A., Awaisheh, S. S., Osaili, T. M., Olaimat, A. N., Rahahaleh, R. J., Al-Dabbas, F. M., Al-Kharabsheh, L. A., Gyawali, R., \& Ibrahim, S. A. (2015). Inactivation of Cronobacter sakazakii in reconstituted infant milk formula by plant essential oils. Journal of Applied Botany and Food Quality, 88, 97-101.

Al-Nabulsi, A. A., Osaili, T. M., Olaimat, A. N., Almasri, W. E., Ayyash, M., Al-Holy, M. A., Jaradat, Z. W., Obaid, R. S., \& Holley, R. A. (2020). Inactivation of Salmonella spp. in tahini using plant essential oil extracts. Food Microbiology, 86, 103338. http://dx.doi.org/10.1016/j. fm.2019.103338. PMid:31703867.

Al-Nabulsi, A. A., Osaili, T. M., Shaker, R. R., Olaimat, A. N., Attlee, A., Al-Holy, M. A., Elabedeen, N. Z., Jaradat, Z. W., \& Holley, R. A. (2013). Survival of E. coli O157:H7 and Listeria innocua in tahini (sesame paste). Journal of Food Agriculture and Environment, 11, 303-306.

Baskaran, S. A., Amalaradjou, M. A. R., Hoagland, T., \& Venkitanarayanan, K. (2010). Inactivation of Escherichia coli O157:H7 in apple juice and apple cider by trans-cinnamaldehyde. International Journal of Food Microbiology, 141(1-2), 126-129. http://dx.doi.org/10.1016/j. ijfoodmicro.2010.04.002. PMid:20442003. 
Boskovic, M., Zdravkovic, N., Ivanovic, J., Janjic, J., Djordjevic, J., Starcevic, M., \& Baltic, M. Z. (2015). Antimicrobial activity of Thyme (Tymus vulgaris) and oregano (Origanum vulgare) essential oils against some food-borne microorganisms. Procedia Food Science, 5, 18-21.

Burt, S. (2004). Essential oils: their antibacterial properties and potential applications in foods: a review. International Journal of Food Microbiology, 94(3), 223-253. http://dx.doi.org/10.1016/j. ijfoodmicro.2004.03.022. PMid:15246235.

Burt, S. A., \& Reinders, R. D. (2003). Antibacterial activity of selected plant essential oils against Escherichia coli O157: H7. Letters in Applied Microbiology, 36(3), 162-167. http://dx.doi.org/10.1046/j.1472765X.2003.01285.x. PMid:12581376.

Centers for Disease Control and Prevention - CDC. (2012). Multistate outbreak of salmonella serotype bovismorbificans infections associated with hummus and tahini in United States, 2011. Atlanta: CDC. Retrieved from https://www.cdc.gov/mmwr/preview/mmwrhtml/ mm6146a3.htm

Centers for Disease Control and Prevention - CDC. (2013). Multistate outbreak of Salmonella Montevideo and Salmonella Mbandaka infections linked to tahini sesame paste. Atlanta: CDC. Retrieved from https://www.cdc.gov/salmonella/montevideo-tahini-05-13/

Ceylan, E., Fung, D. Y. C., \& Sabah, J. R. (2004). Antimicrobial activity and synergistic effect of cinnamon with sodium benzoate or potassium sorbate in controlling Escherichia coli O157:H7 in apple juice. Journal of Food Science, 69(4), FMS102-FMS106. http://dx.doi. org/10.1111/j.1365-2621.2004.tb06348.x.

Dadalioğlu, I., \& Evrendilek, G. A. (2004). Chemical compositions and antibacterial effects of essential oils of Turkish oregano (Origanum minutiflorum), bay laurel (Laurus nobilis), Spanish lavender (Lavandula stoechas L.), and fennel (Foeniculum vulgare) on common foodborne pathogens. Journal of Agricultural and Food Chemistry, 52(26), 8255-8260. http://dx.doi.org/10.1021/jf049033e. PMid:15612826.

Gyawali, R., \& Ibrahim, S. A. (2014). Natural products as antimicrobial agents. Food Control, 46, 412-429. http://dx.doi.org/10.1016/j. foodcont.2014.05.047.

Hammer, K. A., Carson, C. F., \& Riley, T. V. (1999). Antimicrobial activity of essential oils and other plant extracts. Journal of Applied Microbiology, 86(6), 985-990. http://dx.doi.org/10.1046/j.13652672.1999.00780.x. PMid:10438227.

Helander, I. M., Alakomi, H. L., Latva-Kala, K., Mattila-Sandholm, T., Pol, I., Smid, E. J., Gorris, L. G., \& von Wright, A. (1998). Characterization of the action of selected essential oil components on Gram-negative bacteria. Journal of Agricultural and Food Chemistry, 46(9), 35903595. http://dx.doi.org/10.1021/jf980154m.

Hossain, M. A., AL-Raqmi, K. A. S., AL-Mijizy, Z. H., Weli, A. M., \& Al-Riyami Q. (2013). Study of total phenol, flavonoids contents and phytochemical screening of various leaves crude extracts of locally grown Thymus vulgaris. Asian Pacific Journal of Tropical Biomedicine, 3, 705-710.

Hyldgaard, M., Mygind, T., \& Meyer, R. L. (2012). Essential oils in food preservation: Mode of action, synergies, and interactions with food matrix components. Frontiers in Microbiology, 3, 1-24. http://dx.doi. org/10.3389/fmicb.2012.00012. PMid:22291693.

Janakat, S., Al-Nabulsi, A. A. R., Allehdan, S., Olaimat, A. N., \& Holley, R. A. (2015). Antimicrobial activity of amurca (olive oil lees) extract against selected foodborne pathogens. Food Science and Technology, 35(2), 259-265. http://dx.doi.org/10.1590/1678-457X.6508.

Kon, K. V., \& Rai, M. K. (2012). Plant essential oils and their constituents in coping with multidrug-resistant bacteria. Expert Review of Anti-Infective Therapy, 10(7), 775-790. http://dx.doi.org/10.1586/ eri.12.57. PMid:22943401.
Lake, R., King, N., Cressey, P., \& Gilbert, S. (2010). Salmonella (non typhoidal) in high lipid foods made from sesame seeds, peanuts or cocoa beans (Project MRP/08/01). Wellington: New Zealand Food Safety.

Mani-Lopez, E., García, H. S., \& López-Malo, A. (2012). Organic acids as antimicrobials to control Salmonella in meat and poultry products. Food Research International, 45(2), 713-721. http://dx.doi. org/10.1016/j.foodres.2011.04.043.

Naghdi Badi, H., Yazdani, D., Ali, S. M., \& Nazari, F. (2004). Effects of spacing and harvesting time on herbage yield and quality/quantity of oil in thyme, Thymus vulgaris L. Industrial Crops and Products, 19(3), 231-236. http://dx.doi.org/10.1016/j.indcrop.2003.10.005.

Narasimhulu, C. A., Selvarajan, K., Litvinov, D., \& Parthasarathy, S. (2015). Anti-atherosclerotic and anti-inflammatory actions of sesame oil. Journal of Medicinal Food, 18(1), 11-20. http://dx.doi. org/10.1089/jmf.2014.0138. PMid:25562618.

Olaimat, A. N., Al-Holy, M. A., Abu Ghoush, M. A., Al-Nabulsi, A. A., Osaili, T. M., \& Holley, R. A. (2019). Inhibitory effects of cinnamon and thyme essential oils against Salmonella spp. in hummus (chickpea dip). Journal of Food Processing and Preservation, 43(5), e13925. http://dx.doi.org/10.1111/jfpp.13925.

Osaili, T. M., Al-Nabulsi, A. A., Nazzal, D. S., \& Shaker, R. R. (2017). Effect of storage temperatures and stresses on the survival of Salmonella spp. in halva. Letters in Applied Microbiology, 65(5), 403-409. http:// dx.doi.org/10.1111/lam.12791. PMid:28802055.

Osaili, T. M., Al-Nabulsi, A. A., Shaker, R. R., Al-Holy, M. M., Al-Haddaq, M. S., Olaimat, A. N., Ayyash, M. M., Al Ta’ani, M. K., \& Forsythe, S. J. (2010). Efficacy of the thin agar layer method for the recovery of stressed Cronobacter spp. (Enterobacter sakazakii). Journal of Food Protection, 73(10), 1913-1918. http://dx.doi.org/10.4315/0362028X-73.10.1913. PMid:21067681.

Oussalah, M., Caillet, S., \& Lacroix, M. (2006). Mechanism of action of Spanish oregano, Chinese cinnamon, and savory essential oils against cell membranes and walls of Escherichia coli O157:H7 and Listeria monocytogenes. Journal of Food Protection, 69(5), 1046-1055. http://dx.doi.org/10.4315/0362-028X-69.5.1046. PMid:16715803.

Oussalah, M., Caillet, S., Saucier, L., \& Lacroix, M. (2007). Inhibitory effects of selected plant essential oils on the growth of four pathogenic bacteria: E. coli O157:H7, Salmonella typhimurium, Staphylococcus aureus and Listeria monocytogenes. Food Control, 18(5), 414-420. http://dx.doi.org/10.1016/j.foodcont.2005.11.009.

Perricone, M., Arace, E., Corbo, M. R., Sinigaglia, M., \& Bevilacqua, A. (2015). Bioactivity of essential oils: A review on their interaction with food components. Frontiers in Microbiology, 6, 1-16. http:// dx.doi.org/10.3389/fmicb.2015.00076. PMid:25709605.

Prabuseenivasan, S., Jayakumar, M., \& Ignacimuthu, S. (2006). In vitro antibacterial activity of some plant essential oils. $B M C$ Complementary and Alternative Medicine, 6, 39-47. http://dx.doi. org/10.1186/1472-6882-6-39.

Research and Markets. (2017). Global Tahini Food Market - Growth, Trends, and Forecasts (2017-2022). Dublin, Ireland. Retrieved from https:/www.researchandmarkets.com/research/ftdq52/global_tahini

Sawaya, W. N., Ayaz, M., Khalil, J. K., \& Al-Shalhat, A. F. (1985). Chemical composition and nutritional quality of tehineh (sesame butter). Food Chemistry, 18(1), 35-45. http://dx.doi.org/10.1016/03088146(85)90101-3.

Smith-Palmer, A., Stewart, J., \& Fyfe, L. (2001). The potential application of plant essential oils as natural food preservatives in soft cheese. Food Microbiology, 18(4), 463-470. http://dx.doi.org/10.1006/ fmic.2001.0415. 
Solomakos, N., Govaris, A., Koidis, P., \& Botsoglou, N. (2008). The antimicrobial effect of thyme essential oil, nisin and their combination against Escherichia coli O157: $\mathrm{H} 7$ in minced beef during refrigerated storage. Meat Science, 80(2), 159-166. http://dx.doi.org/10.1016/j. meatsci.2007.11.014. PMid:22063318.

Tajkarimi, M. M., Ibrahim, S. A., \& Cliver, D. O. (2010). Antimicrobial herb and spice compounds in food. Food Control, 21(9), 1199-1218. http://dx.doi.org/10.1016/j.foodcont.2010.02.003.

Ultee, A., Kets, E. P. W., \& Smid, E. J. (1999). Mechanisms of action of carvacrol on the food-borne pathogen Bacillus cereus. Applied and Environmental Microbiology, 65(10), 4606-4610. http://dx.doi. org/10.1128/AEM.65.10.4606-4610.1999. PMid:10508096.
Unicomb, L. E., Simmons, G., Merritt, T., Gregory, J., Nicol, C., Jelfs, P., Kirk, M., Tan, A., Thomson, R., Adamopoulos, J., Little, C. L., Currie, A., \& Dalton, C. B. (2005). Sesame seed products contaminated with Salmonella: Three outbreaks associated with tahini. Epidemiology and Infection, 133(6), 1065-1072. http://dx.doi. org/10.1017/S0950268805004085. PMid:16274503.

Yuste, J., \& Fung, D. Y. C. (2004). Inactivation of Salmonella typhimurium and Escherichia coli O157: H7 in apple juice by a combination of nisin and cinnamon. Journal of Food Protection, 67(2), 371-377. http://dx.doi.org/10.4315/0362-028X-67.2.371. PMid:14968972.

Zhang, Y. M., \& Rock, C. O. (2008). Membrane lipid homeostasis in bacteria. Nature Reviews. Microbiology, 6(3), 222-233. http://dx.doi. org/10.1038/nrmicro1839. PMid:18264115. 